УДК 316.334 .23

$10.17213 / 2075-2067-2020-5-162-174$

\title{
СОЦИАЛЬНАЯ ОТВЕТСТВЕННОСТЬ БИЗНЕСА В КОНТЕКСТЕ ТЕОРИИ СТЕЙКХОЛДЕРОВ: ВЗГЛЯД РОССИЙСКИХ ИССЛЕДОВАТЕЛЕЙ
}

\author{
(C) 2020 г. Л. С. Данилова \\ Нижегородский филиал Высшей школы экономики, \\ 2. Нижний Новгород, Россия
}

Целью исследования является рассмотрение концепџии соџиальной ответственности бизнеса (далее - СОБ) с позиции теории стейкхолдеров.

Методологическую базу исследования составляет теория стейкхолдеров Р. Е. Фримана, а также кониепчии, в рамках которых социальная ответственность бизнеса по отношению к заинтересованными сторонам рассматривается современными исследователями («корпоративный эгоизм», «корпоративный альтруизм», «разумный эгоизм»). В качестве основного метода эмпирического исследования выбран многомерный контент-анализ 200 российских публикаций, посвященных вопросам СОБ, за период с 2013 по 2018 год.

Результаты исследования демонстрируют, что в качестве ключевых заинтересованных сторон в аспекте сочиальной ответственности предприятия российскими исследователями выделены государство и общество, отмечен противоречивый характер взаимоотнотений с ними в контексте СОБ. Сделан вывод о том, что при декларируемой значимости всех заинтересованных в российских реалиях организации имеют возможность удовлетворять интересы преимущественно ключевых финансовых стейкхолдеров.

Перспектива исследования заключается в комплексном осмыслении дискурса вокруг вопросов сочиильной ответственности бизнеса в кругах современных российских исследователей, включающем не только аспект стейкхолдеров, но и такие направления в изучении СОБ, как понятийный аппарат, оченка зарубежного опьта, стандартизация и отчетность и т. $\partial$.

Ключевые слова: социиальная ответственность бизнеса; теория стейкхолдеров; стейкхолдеры; государство; общество; работник.

\section{SOCIAL RESPONSIBILITY OF BUSINESS IN THE CONTEXT OF STAKEHOLDER THEORY: A VIEW OF RUSSIAN RESEARCHERS}

\section{(C) 2020 L. S. Danilova}

\section{Nizhny Novgorod branch of the Higher School of Economics, Nizhny Novgorod, Russia}

The aim of the study is to consider the concept of social responsibility of business (further$S R B)$ from the perspective of the theory of stakeholders.

The methodological base of the study is the theory of stakeholders developed by R. E. Freeman, as well as the concepts of social responsibility of business considered by modern researches in relation to stakeholders («corporate egoism», "corporate altruism», «reasonable 
egoism»). The main method of the empirical research is a multivariate content analysis of 200 Russian publications on the issues of SRB for the period from 2013 to 2018.

The results of the study demonstrate that the state and society are identified as key stakeholders in the aspect of social responsibility of business by Russian researchers, and the contradictory nature of relations with them in the context of SRB is noted. It is concluded that despite the declared significance of all those concerned parties, in Russian realities organizations have the opportunity to satisfy the interests predominantly of key financial stakeholders.

The prospect of the study consists in a comprehensive understanding of the discourse around the issues of social responsibility of business in the circles of modern Russian researchers, including not only the aspect of stakeholders, but also such areas in the study of the SRB as the conceptual framework, assessment of foreign experience, standardization and reporting, etc.

Key words: social responsibility of business; stakeholder theory; stakeholders; state; society; employee.

Введение. Новые реалии, связанные с изменением социально-экономической ситуации в России, требуют пересмотра некоторых существующих принципов взаимодействия бизнеса с заинтересованными сторонами, в том числе в аспекте социальной ответственности (СОБ). В связи с экономическим кризисом, вызванным вспышкой коронавирусной инфекции, государство было вынуждено усилить механизмы социальной защиты граждан, сняв при этом часть социальной нагрузки с предприятий, многие из которых оказались в крайне затруднительном финансовом положении. 2020 год, помимо всего прочего, ознаменовался вступлением в силу поправок в Конституцию [17], которые также окажут существенное влияние на социальную ответственность бизнеса: в этом смысле к ключевой для организаций, вероятнее всего, следует отнести изменения в ст. 75 , согласно которым работодатель теперь не может установить минимальный размер оплаты труда ниже прожиточного минимума. Поправки о защите животных, охране природных богатств и т.п. также призваны сделать российские предприятия более социально ответственными.

Итак, рассмотрение вопроса социальной ответственности бизнеса, с точки зрения теории стейкхолдеров, приобретает в настоящее время новое звучание.

Целью исследования является рассмотрение концепции социальной ответственности бизнеса с позиции теории стейкхолдеров. Гипотезы исследования сформулированы следующим образом.
1. Существует некоторое несоответствие между пониманием социальной ответственности с позиции теории стейкхолдеров в исследованиях и реальным положением вещей. В научной литературе декларируется возможность и необходимость равного отношения организаций ко всем заинтересованным сторонам. На практике этот тезис находит применение лишь отчасти: положение российского бизнеса заставляет его удовлетворять интересы преимущественно ключевых стейкхолдеров.

2. Основными стейкхолдерами для бизнеса в России в аспекте социальной ответственности являются государство и общество, при этом в вопросах социальной ответственности бизнес отводит государству системообразующую роль; что же касается общества - организации замечают усиление социального контроля с его стороны, что связано с появлением новых каналов коммуникации между бизнесом и представителями общественности.

Прежде всего, необходимо уточнить некоторые аспекты возникновения теории стейкхолдеров и применения этой теории к вопросам социальной ответственности бизнеса. Считается, что основоположником теории стейкхолдеров является Р.Е. Фриман, который ввел в оборот термин «заинтересованная сторона» и отнес к таким сторонам любые индивидуумы, группы или организации, существенно влияющие на принимаемые фирмой решения и/или оказывающиеся под воздействием этих решений [1]. Очевидно, что вопросы отношений со стейкхолде- 
рами в том или ином виде рассматривались применительно к бизнесу и ранее - появление теории стало методологической основой будущих исследований в этой области.

В то же время основу исследований в области СОБ составляют три теории [4 и др.]. В рамках этих теорий возможно определить в том числе отношение бизнеса к заинтересованным сторонам:

- теория «корпоративного эгоизма», в рамках которой под ответственностью бизнеса подразумевается ответственность только перед акционерами. Данный подход, по сути, придает значимость только одной из заинтересованных сторон;

- теория «корпоративного альтруизма», предполагающая, что бизнес обязан влиять на улучшение качества жизни людей - предоставлять работникам социальные гарантии, участвовать в благотворительной деятельности и т.п. Можно говорить о том, что такая теория предполагает в равной степени внимательное отношение ко всем стейкхолдерам, но особенности к тем, кто в нем более всего нуждается;

- своего рода симбиозом некоторых составляющих описанных выше теорий можно считать теорию «разумного эгоизма», в рамках которой внимание акцентируется на том, что социальная ответственность для организации - это стратегическое мероприятие, «при котором корпорация направляет часть своей текущей прибыли на проведение социальных и благотворительных программ, но в долгосрочной перспективе создает благоприятное социальное окружение и в конечном счете приумножает свою прибыль в будущем» [13, с. 54]. Когда мы рассматриваем этот подход с позиции заинтересованных сторон, кажется логичным утверждение о том, что «разумный эгоизм» предполагает определение группы ключевых стейкхолдеров в зависимости от текущих и стратегических интересов организации.

В России наибольшее распространение получил подход «разумного эгоизма» [12], так как «корпоративный эгоизм» все меньше признается мировым сообществом, а действовать в рамках «корпоративного альтруизма» в российских реалиях объективно крайне сложно.

Методология исследования. Сформировать собственное представление о соци- альной ответственности бизнеса с позиции теории стейкхолдеров авторы посчитали необходимым с помощью систематизации уже существующих взглядов на эту тему. Для этого в базе РИНЦ были отобраны 200 научных публикаций за период с 2013 по 2018 год, так или иначе имеющих отношение к социальной ответственности бизнеса. С помощью ПО «Lekta» был проведен многомерный контент-анализ этих публикаций, что позволило выделить те смысловые отрывки, где в исследованиях говорится о стейкхолдерах. Эти смысловые отрывки также были разбиты на несколько блоков, что позволило определить несколько «сюжетов», которые формируются, когда исследователи пишут о заинтересованных сторонах.

Результаты исследования. В процессе контент-анализа удалось выявить несколько тематик, которые авторы затрагивают, рассматривая вопрос стейкхолдеров в публикациях о социальной ответственности:

- актуальность, необходимость исследования стейкхолдеров;

- теоретическая основа исследования вопроса — определение классификации стейкхолдеров, подходы к анализу;

— государство, работник и общество как основные стейкхолдеры организации;

- некоторые проблемы и решения общего характера.

Необходимость исследования стейкхолдеров

Российские исследователи говорят о необходимости исследования ответственности перед стейкхолдерами с позиции тенденций в экономике и менеджменте. В сфере экономики наблюдается возрастающая роль процессов «глобализации и повсеместной социализации бизнеса» [36], в связи с чем возникает необходимость формирования инновационных подходов к взаимодействию с заинтересованными сторонами. Такие подходы будут способствовать «устойчивому и прогрессивному» развитию экономики [20]. Актуализируется роль социальной ответственности как одного из необходимых для всех заинтересованных сторон в настоящее время элементов управления [2], так как именно постоянное эффективное взаимодействие со стейкхолдерами помогает организациям достигать 
стратегических целей, реализовывать потребность в устойчивом развитии [34 и др.]. Особое внимание получила в некоторых публикациях оценка изменений мнения российского общества и бизнеса об ответственности перед заинтересованными сторонами: так, подчеркивается, что российские компании уже на протяжении довольного долгого времени участвуют в «построении социальных партнерств с различными группами заинтересованных сторон» [18, с. 55], тем не менее, в вопросе формирования устойчивой стратегии взаимодействия со стейкхолдерами российский бизнес находится еще в начале пути.

Подходыл к анализу стейкхолдеров

Перед тем как рассмотреть существующие подходы к анализу стейкхолдеров, необходимо уточнить позицию исследователей по определению этого понятия. Интересно отметить, что оно практически не изменилось по отношению к базовому определению Р.Е. Фримана (см. выше). Вероятнее всего, это связано с тем, что понятие стейкхолдеров как группы лиц, на которые существенно влияет организация или которые подвержены ее существенному влиянию, признано бизнес-сообществом и наукой: так, исследователи, предлагая свое определение стейкхолдеров, преимущественно либо транслируют определение Р.Е. Фримана, либо ссылаются на трактовки, принятые в международных стандартах социальной отчетности (ISO 26000, GRI и др.). Дискуссии подлежит вопрос об определении непосредственно круга стейкхолдеров.

В процессе проведения контент-анализа были выявлены 2 основные классификации, по которым российские исследователи разделяют заинтересованные стороны организации: 1) внутренние и внешние [7 и др.]; 2) финансовые и нефинансовые [24 и др.]. Удивительным оказался факт, что в публикациях многократно упоминается термин «ключевых стейкхолдеров» (что выглядит вполне логичной отсылкой к базовому определению, так как, вероятно, именно ключевые стейкхолдеры должны «существенно влиять» на организацию или «подвергаться ее существенному влиянию»), однако, подход к рассмотрению стейкхолдеров с точки зрения ключевых и второстепенных был описан только в одной из публикаций [29]. Рассмотрим более подробно описанные выше классификации.
Внутренние и внешние стейкхолдеры. В самом общем смысле под внутренними стейкхолдерами понимаются люди (группы, организации), принадлежащие внутреннему окружению организации, под внешними все остальные. При конкретизации круга внутренних стейкхолдеров выделяются всего 2 группы заинтересованных сторон: собственники и сотрудники. Такой подход может быть оправдан не всегда, так как в некоторых случаях зачастую понимаемые в исследованиях синонимично собственники и акционеры могут не иметь (или иметь очень опосредованное) отношение к внутренней среде организации [35].

Финансовые и нефинансовые стейкхолдеры. Под финансовыми стейкхолдерами, как правило, понимаются люди (группы, организации), которые несут в процессе деятельности организации прямые инвестиционные риски (инвесторы, собственники, кредиторы) под нефинансовыми - все остальные.

Недостаток этих классификаций в том, что они довольно четко определяют 2-3 группы заинтересованных сторон и достаточно размыто идентифицируют остальные (которых, в свою очередь, гораздо больше). Возможно, именно по этой причине в большей части научных публикаций, попавших в выборку, авторы не предпринимают попыток систематизировать и сгруппировать стейкхолдеров, ограничиваясь предоставлением некоего перечня заинтересованных сторон. Так, например, Ю.Е. Благов и др. в своих исследованиях выделяют более 20 стейкхолдеров бизнеса, включая «сотрудников компании, менеджеров, советы директоров, собственников и инвесторов, местное сообщество, инициативные общественные группы и организации, некоммерческие организации, потребителей, поставщиков и иных бизнес-партнеров, средства массовой информации» [6, с. 95] и др.

Очевидно, что определение круга стейкхолдеров для современной организации становится одной из ключевых задач, хотя интересует она немногих исследователей социальной ответственности. Те, кто рассматривает этот вопрос, отмечают, что в бизнесе проблемы идентификации и классификации стейкхолдеров решаются с помощью современных управленческих инструментов, та- 
ких как карта стейкхолдеров, реестр стейкхолдеров, сценарное планирование [5]. Тем не менее, в процессе контент-анализа в публикациях довольно четко обозначились три стейкхолдера, интересы которых необходимо принимать во внимание практически всем российским организациям. К этим стейкхолдерам относятся государство, общество (объясняется это, вероятно, тем, что довольно большое количество исследований рассматривают социальную ответственность в триаде «государство-бизнес-общество»), а также работник как определяющий ресурс компании. Рассмотрим оценку российскими исследователями каждого из этих стейкхолдеров в отдельности.

\section{Государство}

В некоторых российских исследованиях государство определяется как основной стейкхолдер бизнеса, в частности, в аспекте социальной ответственности [3 и др.]. Во многом это объясняется развитием института государственно-частного партнерства [9], изменением роли государства в решении социальных проблем [10], к тому же в современных условиях нельзя не принять во внимание кризисные явления, с наступлением которых необходимость государственной поддержки предприятий ощущается наиболее остро.

Разумеется, в публикациях обозначен ряд проблем, препятствующих эффективному взаимодействию государства и бизнеса в России в области социальной ответственности. К числу таких проблем относят следующие:

- несистемную государственную экономическую политику, направленную на активизацию социальной деятельности компаний [19];

- отсутствие современных законодательных инструментов, развивающих ряд направлений социальной ответственности [31];

- отсутствие понимания у государства и организаций степени ответственности за решение социальных проблем [33];

- ограниченный фокус мероприятий, направленных на государственное регулирование социальной ответственности бизнеса: по большому счету, власть накладывает на предприятия некоторые обязательства по, прежде всего, соблюдению требований к безопасности, оплате и условиям труда работников, а также охране и защите окружающей среды [9].
Довольно пристальное внимание в исследованиях уделено решениям, которые могут быть приняты для устранения вышеупомянутых проблем. Предлагаемые решения, с одной стороны, призваны наложить на бизнес некоторые ограничения в виде обязательств и касаются совершенствования законодательства, внедрения социальных стандартов, с другой - направлены на стимулирование организаций добровольно реализовывать социальные проекты [19 и др.], формировать нравственную культуру социально ответственного предпринимательства [14 и др.]. Некоторые исследователи, принимая во внимание факт, что одним из принципов рыночной экономики является минимальное участие государства в делах бизнеса, в том числе в аспекте социальной ответственности, полагают, что характер вмешательства властных структур должен быть, скорее, рекомендательным [11].

\section{Обиество}

Необходимость нести ответственность перед обществом заложена в самой сущности феномена социальной ответственности, ведь «социальный» означает не что иное, как «общественный» [23]. Определения СОБ, предлагаемые в признанных мировым сообществом стандартах, таких как, к примеру, ISO 26000, включают в себя понятие «общество» и гласят: «Социальная ответственность это ответственность организации за воздействие ее решений и деятельности на общество и окружающую среду через прозрачное и этичное поведение, которое способствует устойчивому развитию, включая здоровье и благосостояние общества ...» [40]. Нельзя также не отметить, что бизнес как таковой является институтом, порожденным общественным развитием, поэтому он обязан соответствовать определенным общественным ожиданиям [27].

Одной из методологических проблем исследования социальной ответственности бизнеса перед обществом является проблема определения собственно общества. В некоторых публикациях, посвященных СОБ, акцентируется внимание на том, что общество - это «в том числе потребители продукции и сотрудники компании, а также их семьи» [28, с. 139]. В таком случае социальная ответственность перед обществом сводилась бы к производству качественной 
продукции для потребителей и предоставлению достойных (в широком смысле этого слова) условий труда для работников, чтобы те, в свою очередь, смогли обеспечить достойную жизнь своим семьям. Большая часть исследований основана на восприятии общества в более развернутой трактовке и предполагает рассмотрение самых разных групп, входящих в него, к числу которых могут относиться, к примеру, местные сообщества, некоммерческие организации, СМИ и т.д. (разумеется, не исключая при этом потребителей и сотрудников организаций).

Некоторые исследования, попавшие в выборку, сводят ответственность бизнеса перед обществом к необходимости «соответствовать общественным ожиданиям» [2]. По этой причине разворачивается дискуссия вокруг феномена «общественное мнение» и отмечается, что в последнее время оно становится все более требовательным к бизнесу [32]. В этом смысле кажется необходимым рассмотреть некоторые современные кейсы, наглядно демонстрирующие этот тезис. К примеру, протесты, проходящие в 2020 году в США на фоне борьбы с расизмом и полицейским произволом, заставляют общество пересматривать мнение о некоторых аспектах деятельности организаций, а бизнес — peaгировать на это. По этой причине, например, сотрудники компании Google обратились к руководству с просьбой «остановить продажу технологий правоохранительным органам и таким образом подтвердить свою приверженность в борьбе с расовым неравенством» [37], компания Johnson\&Johnson прекращает выпуск косметики, осветляющей кожу [38], корпорации РеpsiCo и Mars меняют логотипы своих продуктов, «основанные на расистском стереотипе» [39]. В России интерес общества к социальной ответственности бизнеса, несомненно, присутствует, однако выражение общественного мнения в этих вопросах носит более пассивный характер.

Итак, сила общественного давления заставляет предприятия оперативно пересматривать инвестиционные планы и в краткосрочном периоде терпеть убытки. В то же время менеджмент компаний осознает, что игнорирование интересов общества в конечном итоге будет сопряжено с репутационными потерями, негативное влияние которых в стратегической перспективе окажется куда более существенным, чем текущие финансовые издержки. В настоящее время можно однозначно говорить о том, что усиление социального контроля общества (в том числе с появлением новых возможностей выразить собственное мнение - социальные сети и т.п.) является для организаций крайне серьезным стимулом для пересмотра социальной политики.

\section{Работник}

Несмотря на то, что работника как одного из стейкхолдеров социальной ответственности бизнеса следовало бы рассматривать в рамках категории «общество», кажется необходимым вынести этот вопрос отдельно, так как тему СОБ по отношению к работникам можно считать «наболевшей» для российских исследователей: этому вопросу посвящено значительное количество публикаций, в особенности в аспекте проблем, с которыми сотрудники российских организаций сталкиваются на рабочем месте.

В публикациях отмечается, что в современном мире работник и работодатель взаимно заинтересованы в устойчивом развитии организации: работодатели приходят к осознанию роли персонала как ключевого ресурса организации [26 и др.], работники, в свою очередь, признают, что организация, следующая принципам устойчивого развития, способна гарантировать рабочее место и стабильную оплату труда. В исследованиях отмечаются экономические и другие позитивные эффекты от вложений в социальные проекты для сотрудников [16 и др.]: такие проекты повышают их мотивацию и производительность, улучшают имидж организации как работодателя и в конечном счете увеличивают ее прибыль. По мнению некоторых исследователей, достойная оплата и условия труда работников являются индикатором социальной устойчивости бизнеса [21 и др.], а такой бизнес, в свою очередь, в целом повышает благосостояние экономики [16 и др.]

Сложности, возникающие у работников в организации по вине работодателя, составляют ядро дискуссии о социальной ответственности в этой области. В российских научных работах обозначаются следующие проблемы и формы несправедливости, с которыми сталкиваются сотрудники организаций: 
- в российском экономическом контексте конкуренция на рынке труда далека от идеализированной классической модели: все большее распространение получают монопсония и подобные явления [21];

- к наиболее существенным относятся серьезные проблемы в сферах оплаты труда работников [7 и др.], охраны и условий их труда [15 и др.]. Со стороны работодателя это проявляется либо в прямом нарушении трудового законодательства, либо в уклонении от возможностей увеличить фонд заработной платы / улучшить условия труда работников;

- наблюдаются различные формы дискриминации в оплате труда: к примеру, по отношению к женщинам [16], к работникам, находящимся на испытательном сроке [22], к «рядовым» работникам в сравнении с менеджментом [15 и др.];

- профессиональному развитию работников не уделяется достаточно внимания [8].

В российских публикациях на тему социальной ответственности затронуты также проблемы работодателей: в качестве основной отмечена нехватка квалифицированных кадров [21 и др.]. Разумеется, это может стать причиной низкой эффективности производства, как следствие - невозможности финансировать социальные проекты. Тем не менее, нельзя не разделить мнение исследователей о том, что низкая рентабельность предприятия не может быть оправданием несоблюдения принципов социальной ответственности (как минимум, на законодательном уровне).

Важным аспектом в анализе социальной ответственности бизнеса по отношению к работникам является предложение ряда решений, способствующих нейтрализации указанных выше проблем. Отмечается, что на российских предприятиях необходимо внедрять систему страхования [31]; разрабатывать такую культуру предпринимательства, в которой социальные задачи будут такими же важными, как производственные [15]; предоставлять работникам возможности для профессиональной переподготовки и повышения квалификации и т.П. По большому счету, варианты решений, предлагаемые в публикациях, носят довольно абстрактный и очевидный характер. К предложениям, которые можно довольно оперативно внедрить в практическую деятельность, относятся за- ключение между организацией и работниками коллективных договоров [22 и др.], в основу которых заложены совместно определенные интересы работника и работодателя, однако в российском частном бизнесе такая практика не является распространенной.

Проблемь и решения обшего характера

Результаты анализа подчеркивают взаимозависимость и взаимовлияние рассмотренных стейкхолдеров, в связи с чем заинтересованность каждой из сторон в эффективном взаимодействии должна казаться очевидной. Тем не менее, на практике, по мнению российских исследователей, механизмы взаимодействия бизнеса с государством и обществом в контексте социальной ответственности несовершенны по следующим причинам:

- в Российской Федерации в действительности нет стейкхолдеров, готовых взять на себя обязательства стать «двигателем» в развитии СОБ [6];

- взаимодействие государства, бизнеса и общества в России в целом носит конфликтный характер в связи с «борьбой» за использование ограниченных ресурсов [35];

- для бизнеса управление взаимодействием со стейкхолдерами воспринимается скорее как управление рисками, нежели возможность совместного создания ценности [6].

Вполне очевидно, что в качестве основного решения описанных выше проблем предлагается формирование такой системы социальной ответственности, которая будет учитывать интересы всех заинтересованных сторон [9 и др.]. Это возможно в том числе благодаря повышению значимости таких стейкхолдеров, как органы местного самоуправления, объединения работодателей и профсоюзы [25]. В настоящее время остаются не вполне определенными практические механизмы создания такой системы. Сейчас же для бизнеса выход видится в разработке концепции позиционирования в сфере социальной ответственности путем определения приоритетных стейкхолдеров, их постоянного анализа и оценки [30].

Заключение. Результаты проведенного исследования в целом подтверждают выдвинутые гипотезы.

1. В научной литературе выдвигаются обоснованные точки зрения о необходимос- 
ти в равной степени учитывать мнения всех заинтересованных сторон в вопросах реализации КСО. Тем не менее, в российских реалиях организации стремятся к удовлетворению интересов преимущественно ключевых стейкхолдеров, но даже это делается не всегда: к примеру, признается важность работника как важнейшего ресурса организации, однако повсеместные нарушения трудового законодательства говорят об обратном. В условиях недостаточно развитой культуры предпринимательства круг ключевых стейкхолдеров сводится к «финансовым» стейкхолдерам.

2. Основными стейкхолдерами для бизнеса в России можно считать общество и государство. Оценка государства как системообразующего стейкхолдера КСО продиктована, скорее, нежеланием и отсутствием у бизнеса ресурсов взять такую роль на себя (полностью или в равной степени с остальными заинтересованными сторонами) и несколько противоречит концепции о том, что организации, власть и общество в равной степени заинтересованы в реализации принципов социальной ответственности.

Ответственность бизнеса перед обществом в настоящее время принимает новые формы: появление современных технологий, позволяющих представителям общества публично выражать мнение о реализации КСО в организациях, заставляет их оперативно реагировать на общественные мнения, в том числе с целью избегания финансовых и нефинансовых рисков.

Таким образом, возникающие в последнее время вызовы системе социальных отношений могут стать своего рода «триггером» изменений направления научной дискуссии по вопросам стейкхолдеров социальной ответственности бизнеса. В этом смысле обсуждение может стать более «полярным», так как, с одной стороны, наблюдается усиление социальной роли государства, появление в условиях кризиса нетипичных, даже стихийных, форм социальной ответственности предприятий (помощь медикам, пенсионерам и т.д.), с другой - объективное сокращение финансовых ресурсов организаций, как следствие - невозможность исполнять даже минимальные социальные обязательства перед государством и обществом.

\section{Литература}

1. Freeman R.E. Strategic management: stakeholder approach. — Boston: Pitman Publishing. $-1984 .-275 \mathrm{p}$.

2. Абдокова Л. 3. Корпоративная социальная ответственность как основа корпоративного гражданства и социального партнерства в бизнесе // Успехи современной науки и образования. - 2017. - Т. 2. - №1. - С. 139-141.

3. Аксенов В.А., Богатишева Ю.Н., Любимова М.В. Региональный аспект корпоративной социальной ответственности // Управленческие науки. - 2013. - №2. - С. 46-57.

4. Астафьев В.А., Писклакова С. В. Формирование российской модели социальной ответственности бизнеса // Социогуманитарный вестник. - 2013. - №3 (12). - С. 33-38.

5. Басова М.М. Основные проблемы корпоративной социальной ответственности бизнеса и пути их решения // Стратегии бизнеса. - 2017. — №2. - C. 16-20.

6. Благов Ю.Е., Кабалина В.И., Петрова-Савченко А. А., Соболев И.С. Создание ценности для бизнеса и общества: анализ корпоративной социальной деятельности российских компаний // Российский журнал менеджмента. - 2015. - Т. 13. - №2. C. 67-98.

7. Виттенберг Е.Я. Социальная ответственность российского бизнеса в условиях кризиса // Вестник института социологии. 2017. - T. 8. - №1 (20). - С. 76-115.

8. Выборный А.Б. Корпоративная социальная ответственность и обеспечение устойчивости и конкурентоспособности предпринимательских структур // МИР (Модернизация. Инновации. Развитие). — 2013. №15. - С. 79-83.

9. Герасимова В.В., Мансуров А.М. Социальная ответственность в развитии партнерских отношений государства и бизнеса// Вестник ПАГС. - 2013. — №4 (37). C. $49-55$.

10. Гончарова А. В., Агафонова М. С. Социальная ответственность работодателей и ее современная роль в формировании социальной политики в России // Научное обозрение. Экономические науки. - 2016. - №2. C. 64-67.

11. Гориенина Е. В., Вицелярова К. Н. Социальная ответственность и культура пред- 
принимательства // Экономические исследования. - 2017. - №3.

12. Емельянов С.M. Корпоративная социальная ответственность в стратегии современной компании: методологические подходы // Управленческое консультирование. 2014. — №5 (65). — C. 73-85.

13. Захаров В. В., Новгородова Н. С., Подворотова Д. М. Корпоративная социальная ответственность // Экономика и управление в XXI веке: тенденции развития. - 2013. №13. - С. 53-59.

14. Ивашина М.М. Корпоративная социальная ответственность как инструмент реализации социальной составляющей российской экономической системы // Наука и общество. - 2015. - №4 (23). - С. 57-60.

15. Иикинина М.X. Социальная ответственности предприятия перед работниками// Вестник ВЭГУ. — 2013. — №2 (64). C. 179-183.

16. Ковалева Н.Н., Дворецкая Ю.А. Социальный аудит в призме социальной ответственности организаций // Вестник БГУ. 2014. - №3. - С. 278-283.

17. Конституция Российской Федерации (принята всенародным голосованием 12 декабря 1993 года с изменениями, одобренными в ходе общероссийского голосования 01.07.2020) [Электронный ресурс] — Режим доступа: http://www.consultant.ru/document/ cons doc LAW 28399/.

18. Мальичева E.A. Практика развития компаний в условиях социально-ориентированного управления // Вестник Самарского муниципального института управления. 2017. — №1. - С. 47-57.

19. Мантаева Э.И., Голденова В. С. О роли социальной ответственности бизнеса на региональном уровне (на материалах Республики Калмыкия) // Вестник РУДН. Серия: Экономика. - 2014. - №4. - С. 104-112.

20. Матакаева Ф. Ю. Проблема оценки качества реализации политики корпоративной социальной ответственности интегрированного бизнес-кластера // Вестник СевероОсетинского государственного университета имени К.Л. Хетагурова. - 2013. - №4. С. 437-442.

21. Морозов A. A. Социальная ответственность бизнеса в системе «работник-работодатель»: опыт эмпирического изучения //
Труды Карельского научного центра РАН. 2015. - №3. - C. 117-125.

22. Нуртдинова А. Ф. Социальная ответственность бизнеса: правовые аспекты экономической концепции // Журнал российского права. - 2015. — №1 (217). — С. 30-46.

23. Ожегов С.И., Шведова Н.Ю. Толковый словарь русского языка: 80000 слов и фразеологических выражений. 4-е изд. М.: Высшая школа, 1993. - 944 с.

24. Петрунин Ю. Ю., Пурлик В. М. Корпоративная социальная ответственность: поиск методологических оснований // Вестник Московского университета. Серия 21. Управление (государство и общество). - 2015. №3. - С. 19-33.

25. Савина Т.Н., Сульдина О.В. Институциональные предпосылки становления и развития социальной ответственности бизнеса в России // Научное обозрение. Экономические науки. - 2014. - №2. - С. 82.

26. Савина T.Н. Практика реализации корпоративной социальной ответственности: опыт ПАО «Лукойл» // Экономический анализ: теория и практика. - 2016. №2 (449). - С. 91-102.

27. Строков М.А., Рудакова О.В. Социальная ответственность бизнеса как его конкурентное преимущество // Среднерусский вестник общественных наук. - 2017. №3. - С. 108-115.

28. Сушкова И.А. Корпоративная социальная ответственность на практике // Экономика. Право. Печать. Вестник КСЭИ. 2013. - №3. - C. 139-143.

29. Трещуевский Ю.И., Никитина Л.М. Методология исследования корпоративной социальной ответственности // Социально-экономические явления и процессы. 2010. — №3 (19). — С. 244-248.

30. Фролов Д.П., Рожков С.А. Эволюция института социальной ответственности бизнеса в России: логика, форматы, фактор Всемирной торговой организации // Национальные интересы: приоритеты и безопасность. - 2013. - Т. 9. — №21 (210). C. 2-12.

31. Черепанов С.В. Страхование как инструмент социальной защиты работников в системе корпоративной социальной ответственности // Актуальные проблемы экономики и права. — 2013. — №2 (26). — С. 147-151. 
32. Чернышева Ю.Г., Шепеленко Г.И. Социальная ответственность предпринимателя // Финансовые исследования. - 2015. №4 (49). - С. 271-276.

33. Чубарова М. С., Евстратова Т.А. Концепция социальной ответственности бизнеса // Материалы Ивановских чтений. - 2017. №3-1 (14). — С. 168-174.

34. Шорохова Н.А. Социальная ответственность как базовая ценность культуры предпринимательства // Вестник Института экономики и управления Новгородского государственного университета им. Ярослава Мудрого. — 2016. - №1 (20). — С. 61-66.

35. Шулимова А. А. Институциональные проблемы развития социально-экономической ответственности российского бизнеса // Национальные интересы: приоритеты и безопасность. - 2014. — №9 (246). - С. 56-64.

36. Яровинская М. С. Инвестиции в социальную ответственность как опцион роста // Управленческие науки. — 2013. — №1 (6). C. 26-31.

37. Bloomberg: сотрудники Google попросили руководство прекратить сотрудничество с полицией [Электронный ресурс] — Режим доступа: https://tass.ru/ekonomika/8792755.

38. Johnson \& Johnson перестанет выпускать осветляющую кожу косметику [Электронный ресурс] - Режим доступа: https:// www.rbc.ru/business/20/06/2020/5eedd02d9a79 $47397565 \mathrm{c} 3 \mathrm{a} 3$.

39. PepsiCo и Mars меняют логотипы продуктов в рамках борьбы с расизмом [Электронный ресурс] - Режим доступа: https://tass.ru/obschestvo/8756295?utm source $=$ yxnews\&utm medium $=$ desktop\&utm referrer $=$ https $\% \overline{3} \mathrm{~A} \% 2 \mathrm{~F} \% 2 \mathrm{Fy}$ andex . $\mathrm{ru} \% 2$ Fnews.

40. ISO 26000 «Руководство по социальной ответственности» [Электронный ресурс] - Режим доступа: http://rspp. ru/simplepage/iso-26000-rukovodstvo-posotsialnoy-otvetstvennosti/.

\section{References}

1. Freeman R.E. Strategic management: stakeholder approach. - Boston: Pitman Publishing. - 1984. - $275 \mathrm{p}$.

2. Abdokova L.Z. Korporativnaja social'naja otvetstvennost' kak osnova korporativnogo grazh- danstva i social'nogo partnerstva $\mathrm{v}$ biznese [Corporate social responsibility as the basis of corporate citizenship and social partnership in business] // Uspehi sovremennoj nauki i obrazovanija [Successes of modern science and education]. 2017. - Vol. 2. — №1. - Pp. 139-141.

3. Aksenov V.A., Bogatishheva Ju. N., Ljubimova $M$. $V$. Regional'nyj aspekt korporativnoj social'noj otvetstvennosti [Regional aspect of corporate social responsibility] // Upravlencheskie nauki [Managerial Sciences]. — 2013. №2. - Pp. 46-57.

4. Astaf'ev V. A., Pisklakova S. V. Formirovanie rossijskoj modeli social'noj otvetstvennosti biznesa [Formation of the Russian model of social responsibility of business] // Sociogumanitarnyj vestnik [Socio-Humanitarian Bulletin]. 2013. - №3 (12). — Pp. 33-38.

5. Basova M.M. Osnovnye problemy korporativnoj social'noj otvetstvennosti biznesa i puti ih reshenija [Basic problems of corporate social responsibility and ways of their solution] // Strategii biznesa [Business Strategy]. 2017. — №2. — Pp. 16-20.

6. Blagov Ju. E., Kabalina V.I., PetrovaSavchenko A. A., Sobolev I. S. Sozdanie cennosti dlja biznesa i obshhestva: analiz korporativnoj social'noj dejatel'nosti rossijskih kompanij [Creating value for business and society: corporate social performance of Russian companies]// Rossijskij zhurnal menedzhmenta [Russian journal of management]. - 2015. - Vol. 13. №2. - Pp. 67-98.

7. Vittenberg E. Ja. Social'naja otvetstvennost' rossijskogo biznesa $\mathrm{v}$ uslovijah krizisa [Social responsibility of Russian business in the crisis] // Vestnik instituta sociologii [Bulletin of the Institute of sociology]. — 2017. — Vol. 8. №1 (20). - Pp. 76-115.

8. Vybornyj A.B. Korporativnaja social'naja otvetstvennost' i obespechenie ustojchivosti i konkurentosposobnosti predprinimatel'skih struktur [Corporate social responsibility and ensuring sustainability and competitiveness of business structures] // MIR (Modernizacija. Innovacii. Razvitie) [MID (Modernization. Innovations. Development)]. — 2013. — №15. Pp. 79-83.

9. Gerasimova V.V., Mansurov A.M. Social'naja otvetstvennost' $v$ razvitii partnerskih otnoshenij gosudarstva i biznesa [Social responsibility in the development of partnership relations between 
the state and business] // Vestnik PAGS [PAGS Bulletin]. — 2013. — №4(37). — Pp. 49-55.

10. Goncharova A.V., Agafonova M.S. Social'naja otvetstvennost' rabotodatelej i ee sovremennaja rol' $\mathrm{v}$ formirovanii social'noj politiki $\mathrm{v}$ Rossii [Social responsibility of employers and its modern role in the formation of social policy in Russia] // Nauchnoe obozrenie. Jekonomicheskie nauki [Scientific review. Economic Sciences]. - 2016. - №2. - Pp. 64-67.

11. Gorshenina E.V., Viceljarova K.N. Social'naja otvetstvennost' i kul'tura predprinimatel'stva [Social responsibility and business culture] // Jekonomicheskie issledovanija [Economic study]. — 2017. — №3.

12. Emel'janov S. M. Korporativnaja social'naja otvetstvennost' $\mathrm{v}$ strategii sovremennoj kompanii: metodologicheskie podhody [Corporate social responsibility in the strategy of a modern company: methodological approaches]// Upravlencheskoe konsul'tirovanie [Management consulting]. — 2014. — №5 (65). Pp. 73-85.

13. Zaharov V.V., Novgorodova N.S., Podvorotova D. M. Korporativnaja social'naja otvetstvennost' [Corporate social responsibility] // Jekonomika i upravlenie $\mathrm{v}$ XXI veke: tendencii razvitija [Economics and management in the XXI century: development trends]. — 2013. №13. - Pp. 53-59.

14. Ivashina M.M. Korporativnaja social'naja otvetstvennost' kak instrument realizacii social'noj sostavljajushhej rossijskoj jekonomicheskoj sistemy [Corporate social responsibility as a tool for implementing the social component of the Russian economic system] // Nauka i obshhestvo [Science and society]. - 2015. - №4 (23). - Pp. 57-60.

15. Ishkinina M.H. Social'naja otvetstvennosti predprijatija pered rabotnikami [Social responsibility of the enterprise to employees] // Vestnik VJeGU. — 2013. — №2 (64). — Pp. 179-183.

16. Kovaleva N.N., Dvoreckaja Ju. A. Social'nyj audit v prizme social'noj otvetstvennosti organizacij [Social audit in the prism of social responsibility of organizations] // Vestnik BGU [Bulletin of BSU]. - 2014. — №3. - Pp. 278-283.

17. Konstitucija Rossijskoj Federacii (prinjata vsenarodnym golosovaniem 12 dekabrja 1993 goda s izmenenijami, odobrennymi v hode obshherossijskogo golosovanija 01.07.2020) [The Constitution of the Russian Federation (adopted by popular vote on December 12, 1993 with changes approved during the all-Russian vote on 01.07.2020)] [Jelektronnyj resurs] — URL: http://www.consultant.ru/document/cons_ doc_LAW 28399/.

18. Mălysheva E.A. Praktika razvitija kompanij $\mathrm{v}$ uslovijah social'no-orientirovannogo upravlenija [Practice of company development in the conditions of socially-oriented management]// Vestnik Samarskogo municipal'nogo instituta upravlenija [Bulletin of the Samara municipal Institute of management]. — 2017. №1. - Pp. 47-57.

19. Mantaeva Je. I., Goldenova V.S. O roli social'noj otvetstvennostibiznesa na regional'nom urovne (na materialah Respubliki Kalmykija) [On the role of social responsibility of business at the regional level (based on the materials of the Republic of Kalmykia)] // Vestnik RUDN. Serija: Jekonomika [Series: Economy]. — 2014. №4. - Pp. 104-112.

20. Matakaeva F. Ju. Problema ocenki kachestva realizacii politiki korporativnoj social'noj otvetstvennosti integrirovannogo biznes-klastera [The problem of assessing the quality of implementation of the corporate social responsibility policy of an integrated business cluster] // Vestnik Severo-Osetinskogo gosudarstvennogo universiteta imeni K.L. Hetagurova [Bulletin of the North Ossetian state University named after K.L. Khetagurov]. 2013. - №4. - Pp. 437-442.

21. Morozov A.A. Social'naja otvetstvennost' biznesa v sisteme «rabotnik-rabotodatel'»: opyt jempiricheskogo izuchenija [Social responsibility of business in the «employee-employer» system: experience of empirical study] // Trudy Karel'skogo nauchnogo centra RAN [Proceedings Karelian research centre of RAS]. 2015. - №3. - Pp. 117-125.

22. Nurtdinova A.F. Social'naja otvetstvennost' biznesa: pravovye aspekty jekonomicheskoj koncepcii [The Social responsibility of business: legal aspects of economic concepts] // Zhurnal rossijskogo prava [Journal of Russian law]. — 2015. — №1 (217). — Pp. 30-46.

23. Ozhegov S.I., Shvedova N. Ju. Tolkovyj slovar' russkogo jazyka: 80000 slov i frazeologicheskih vyrazhenij. 4-e izd. [Dictionary of the Russian language: 80000 words and phraseological expressions. 4th ed.]. - Moscow: Vysshaja shkola, 1993. - $944 \mathrm{p}$. 
24. Petrunin Ju. Ju., Purlik V.M. Korporativnaja social'naja otvetstvennost': poisk metodologicheskih osnovanij [Corporate social responsibility: search for methodological grounds]// Vestnik Moskovskogo universiteta. Serija 21. Upravlenie (gosudarstvo i obshhestvo) [Bulletin of the Moscow University. Series 21. Management (state and society)]. — 2015. №3. - Pp. 19-33.

25. Savina T.N., Sul'dina O.V. Institucional'nye predposylki stanovlenija i razvitija social'noj otvetstvennosti biznesa v Rossii [Institutional prerequisites for the formation and development of social responsibility of business in Russia] // Nauchnoe obozrenie. Jekonomicheskie nauki [Scientific review. Economic Sciences]. 2014. - №2. - P. 82.

26. Savina T.N. Praktika realizacii korporativnoj social'noj otvetstvennosti: opyt PAO «Lukojl» [Practice of implementing corporate social responsibility: experience of PJSC «Lukoil»] // Jekonomicheskij analiz: teorija i praktika [Economic analysis: theory and practice]. — 2016. №2 (449). - Pp. 91-102.

27. Strokov M.A., Rudakova O.V. Social'naja otvetstvennost' biznesa kak ego konkurentnoe preimushhestvo [Social responsibility of business as its competitive advantage] // Srednerusskij vestnik obshhestvennyh nauk [Central Russian Bulletin of social Sciences]. — 2017. №3. - Pp. 108-115.

28. Sushkova I. A. Korporativnaja social'naja otvetstvennost' na praktike [Corporate social responsibility in practice] // Jekonomika. Pravo. Pechat' [Economy. Right. Print]. Vestnik KSJeI. - 2013. - №3. - Pp. 139-143.

29. Treshhevskij Ju. I., Nikitina L.M. Metodologija issledovanija korporativnoj social'noj otvetstvennosti [Methodology of corporate social responsibility research] // Social'no-jekonomicheskie javlenija i processy [Socio-economic phenomena and processes]. - 2010. №3 (19). - Pp. 244-248.

30. Frolov D.P., Rozhkov S.A. Jevoljucija instituta social'noj otvetstvennosti biznesa $\mathrm{V}$ Rossii: logika, formaty, faktor Vsemirnoj torgovoj organizacii [The evolution of the Institute of social responsibility of business in Russia: logic, formats, factor world trade organization] // Nacional'nye interesy: prioritety i bezopasnost' [National interests: priorities and security]. 2013. - Vol. 9. — №21 (210). — Pp. 2-12.
31. Cherepanov $S$. $V$. Strahovanie kak instrument social'noj zashhity rabotnikov v sisteme korporativnoj social'noj otvetstvennosti [Insurance as a tool of social protection of workers in the system of corporate social responsibility] // Aktual'nye problemy jekonomiki i prava [Current problems of Economics and law]. 2013. - №2 (26). - Pp. 147-151.

32. Chernysheva Ju. G., Shepelenko G.I. Social'naja otvetstvennost' predprinimatelja [Social responsibility of the entrepreneur] // Finansovye issledovanija [Financial research]. 2015. - №4 (49). — Pp. 271-276.

33. Chubarova M.S., Evstratova T.A. Koncepcija social'noj otvetstvennosti biznesa [The Concept of social responsibility of business]// Materialy Ivanovskih chtenij [Materials of Ivanovo readings]. — 2017. — №3-1 (14). Pp. 168-174.

34. Shorohova N.A. Social'naja otvetstvennost' kak bazovaja cennost' kul'tury predprinimatel'stva [Social responsibility as the basic value of business culture] // Vestnik Instituta jekonomiki i upravlenija Novgorodskogo gosudarstvennogo universiteta im. Jaroslava Mudrogo [Bulletin of the Institute of Economics and management of the Novgorod state University of Yaroslav Mudry]. — 2016. №1 (20). - Pp. 61-66.

35. Shulimova A.A. Institucional'nye problemy razvitija social'no-jekonomicheskoj otvetstvennosti rossijskogo biznesa [Institutional problems of development of social and economic responsibility of Russian business] // Nacional'nye interesy: prioritety i bezopasnost' [National interests: priorities and security]. - 2014. №9(246). 一 - Pp. 56-64.

36. Jarovinskaja M.S. Investicii v social'nuju otvetstvennost' kak opcion rosta [Investment in social responsibility as a growth option] // Upravlencheskie nauki [Management Sciences]. 2013. - №1 (6). - Pp. 26-31.

37. Bloomberg: sotrudniki Google poprosili rukovodstvo prekratit' sotrudnichestvo s policiej [Bloomberg: Google employees asked the management to stop cooperating with the police] [Jelektronnyj resurs] — URL: https://tass.ru/ ekonomika/8792755.

38. Johnson \& Johnson perestanet vypuskat' osvetljajushhuju kozhu kosmetiku [Johnson \& Johnson will stop producing skin-lightening cosmetics] [Jelektronnyj resurs] — URL: https://www.rbc.ru/ business/20/06/2020/5eedd02d9a7947397565c3a3. 
39. PepsiCo i Mars menjajut logotipy produktov $\mathrm{v}$ ramkah bor'by s rasizmom [PepsiCo and Mars change product logos as part of the fight against racism] [Jelektronnyj resurs] URL: https://tass.ru/obschestvo/8756295?utm source=yxnews\&utm medium $=$ desktop\&utm referrer $=$ https $\% 3 \mathrm{~A} \% 2 \overline{\mathrm{F}} \% 2$ Fyandex.ru $\% 2$ Fnews.
40. ISO 26000 «Rukovodstvo po social'noj otvetstvennosti» [ISO 26000 "Guide to social responsibility»] [Jelektronnyj resurs] — URL: http://rspp.ru/simplepage/iso-26000-rukovodstvo-po-sotsialnoy-otvetstvennosti/.

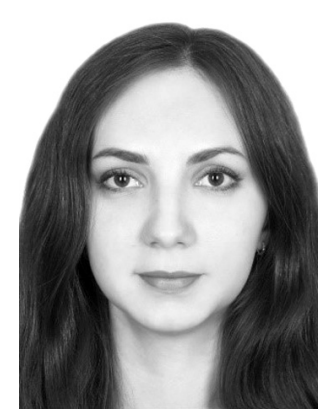

Данилова Любовь Сергеевна - преподаватель кафедры общего и стратегического менеджмента Национального исследовательского университета «Высшая школа экономики»; аспирант факультета социальных наук Нижегородского государственного университета им. Н. И. Лобачевского.

Danilova Liubov Sergeevna - Lecturer, Faculty of Management, Department of General and Strategic Management, National Research University Higher School of Economics; Postraduate student, Faculty of Social Sciences, Lobachevsky State University.

603011, г. Нижний Новгород, ул. Окская, 2

2 Okskaya st., 603011, Nizhny Novgorod, Russia

E-mail: 1danilova@hse.ru 